\title{
Ophthalmic, hematologic and serologic findings in dogs with suspected Ehrlichia canis infections*
}

\section{Achados oftálmicos, hematológicos e sorológicos em cães com suspeita de infecção pela Ehrlichia canis}

\author{
Arianne P. Oriá, ${ }^{* * a}$ Francisco A. Dórea Neto, ${ }^{* \star a}$ Rosangela Z. Machado, ${ }^{* *}$ Áureo E. Santana, ${ }^{* *}$ José L. Guerra, ${ }^{* * *}$ \\ Valérie L. D. da Silva, ${ }^{* * a}$ Peter G. C. Bedford ${ }^{* * *}$ and José L. Laus ${ }^{* *}$
}

\begin{abstract}
The objective of the present study was to correlate ophthalmic and haematological findings, compared with the serological data obtained by indirect fluorescent antibody test (IFATT) and by dot-blot linked immunoassay (DBELIA) in 51 dogs with uveitis due to possible ehrlichiosis infection. Thirty-four positive IFAT and forty-four positive DBELIA results were obtained in serum samples. The high correlation between uveitis and a positive serology for Ehrlichia canis was established. The DBELIA test was more sensitive for the diagnosis of ehrlichiosis than IFAT.
\end{abstract}

keywords: uveitis, Ehrlichia canis, dog, indirect fluorescent antibody test, dot-blot Enzyme linked immunoassay.

\section{Resumo}

O objetivo do presente trabalho foi correlacionar os achados oftálmicos e hematológicos, comparados aos dados sorológicos obtidos por meio da reação de imunofluorescência indireta (RIFI) e dot-blot ELISA (DBELIA) de 51 cães com uveíte, possivelmente devido a erliquiose. Trinta e quatro soros sangüíneos foram positivos pela RIFAT e quarenta e quatro pelo DBELIA. Foi estabelecida uma alta correlação entre uveíte e sorologia positiva para a Ehrlichia canis. O DBELIA foi mais sensível para o diagnóstico da erliquiose comparativamente a RIFI.

Palavras-chave: uveíte, Ehrlichia canis, cão, imunofluorescência indireta, dot-blot ELISA.

\section{Introduction}

Ehrlichiosis is a tick-borne disease caused by the obligate intracellular parasite Ehrlichia canis (Troy and Forrester, 1990). Clinical signs develop after an incubation period ranging from 8 to 20 days, and there is subsequent progression through the acute, sub- clinical and chronic phases of the disease (Harrus et al., 1997; Neer, 1998). A wide range of clinical signs present and the ocular features involve almost every structure of the eye (RISTIC et al., 1972; Collins and Moore, 1999). The severity of the ocular involvement varies from patient to patient (Stiles, 2000).

In experimentally infected dogs, the ocular lesions may present during the acute phase in about $50 \%$ of the inoculated dogs (Martin, 1999). The prevalence of ocular lesions ranges from $10 \%$ to $15 \%$ (Martin, 1999), and include conjunctival hemorrhages, episcleral congestion, anterior chamber flare, rubeosis iridis, miosis, corneal opacitation, keratic precipitates, hypopyon, hyphaema and reduced intra-ocular pressure (Glaze and Gaunt, 1986; Clerc and Laforge, 1999; Stiles, 2000). Inflammatory debris can obstruct the trabecular meshwork to induce secondary glaucoma, and annular posterior synechiae can result in iris bombé formation (Collins and Moore, 1999). Posterior segment lesions include papilledema and chorioretinitis (Glaze and Gaunt, 1986). The severe thrombocytopenia causes retinal hemorrhages and hyphema, and conjunctival petechiae may be seen in the chronic phase of the disease (Glaze and Gaunt, 1986). Frequent hemorrhages may induce secondary retinal detachment (Evermann, 1998; Martin, 1999). Optic neuritis and retinal blood vessel engorgement may also be present (Martin, 1999; STILES, 2000). Tortuosity of retinal blood vessels together with chorioretinal lesions develop in the centrally pigmented hyperreflective areas (Harrus et al., 1997).

Diagnosis of ehrlichiosis is usually made on the basis of the presenting clinical signs together with positive serological

* Financial support by FAPESP - Fundação de Amparo a Pesquisa do Estado de São Paulo (\#99/09479-8 and 00/03737-4), CNPQ - Conselho Nacional de Desenvolvimento Científico e Tecnológico.

** Veterinary College, São Paulo State University, UNESP. Via de Acesso Prof. Paulo Donato Castellane s/n, CEP 14884-900, Jaboticabal, São Paulo, Brazil; Tel: 5516 32092626, Fax: 5516 32024275, e-mail: jllaus@fcav.unesp.br.

a Bolsista FAPESP

*** Universidade de São Paulo -- USP

${ }^{* * * *}$ The Royal Veterinary College, University of London, United kindom. 
findings and the presence of a thrombocytopenia (Evermann, 1998; Neer, 1998). The indirect immunofluorescent antibody test (IFAT) has been rarely used, since it requires specialized laboratory services (Cadman et al., 1994). However values for the dot-blot enzyme linked immunoassay technique (DBELIA) have been correlated with serological titers obtained by the IFAT test (Cadman et al., 1994). Hence, using the Immunocomb test - (Biogal) based on the DBELIA technique, it is possible to determine IgG antibodies specific for the organism (Castro, 1997).

The present study was conducted because of the high incidence of uveitis in dogs at the Ophthalmology Section of São Paulo State University in which the hematological findings indicated that the probable cause was $E$. canis infection.

\section{Materials and methods}

\section{Patients and the ophthalmic examination}

The patient population was consisted by 51 cross and purebred dogs of both sexes presenting for the diagnosis and treatment of uveitis at the Ophthalmology Section of São Paulo State University, UNESP, Jaboticabal, Brazil.

The ophthalmic examination included assessment of the pupillary light reflex, the Schirmer tear test, fluorescein staining, slit-lamp biomicroscopy (Portable Slit Lamp SL - 14, Kowa), applanation tonometry (Tonopen XL-Mentor O \& O, Norwell, MA USA), and indirect ophthalmoscopy.

\section{Serological test - IFAT and DBELIA}

A complete blood cell count (CBC) was performed, together with the indirect immunofluorescent antibody (IFAT), and the dot-blot enzyme linked immunoassay (DBELIA) tests. The serum of each animal was stored in sterile $1 \mathrm{ml}$ bottles kept at $-20^{\circ} \mathrm{C}$, until processing for both IFAT and DBELIA.

In the IFAT test, sera diluted to 1:20 which reacted were considered positive for Ehrlichia canis. In these patients Ehrlichia canis was subsequently cultured using a DH82 cell culture substrate (VMRD Inc., Pullman, WA, A). In addition a modified D'Ell Porto (1986) technique was used to identify possible Babesia sp., using dilutions of 1:80 and 1:160.

The Immunocomb ${ }^{\circledR}-$ BIOGAL test based on the DBELIA technique was used in an attempt to determine IgG antibodies specific for Ehrlichia canis.

\section{Statistical Analysis}

The quantified data of CBC in dogs were analyzed by Fisher's Exact Test. The animals with positive or negative serology at DBELIA were analyzed separately. Fisher's Exact test was used for comparison between DBELIA and IFAT and the measured associated parameters were evaluated by Pearson's Correlation test.

\section{Results}

\section{Ophthalmic findings}

The ophthalmic features varied among the 51 DBELIA positive animals (86.27\%). Iridocyclytis, posterior uveitis and panuveitis were seen in 75 out of the 102 eyes studied (Fig. 1 - 2); 24 dogs had glaucoma secondary to the uveitis, and 3 exhibited phthisis bulbi. Ocular discharge was observed in $44.11 \%$ of the animals; there was episcleral congestion in $72.54 \%$, ciliary flush in $28.43 \%$, corneal edema in $62.74 \%$, keratic precipitates in $15.68 \%$, flare in $22.54 \%$, hyphema in $8.82 \%$, iris swelling in $33.33 \%$, rubeosis iridis in $25.49 \%$, darkening of the iris in $9.8 \%$, retinal detachment in $12.74 \%$, increased tortuosity of retinal vessels in $23.52 \%$, retinal hemorrhage in $11.76 \%$ (Fig. 3), and increased tapetal reflectivity in $11.76 \%$.

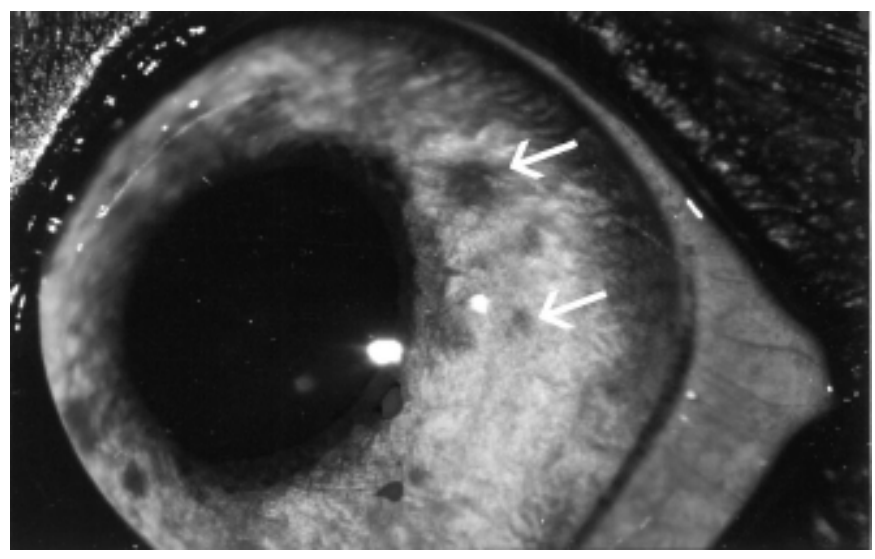

Figure 1: Eye of a dog. Note the hemorrhagic spots (arrows) on the iris surface.

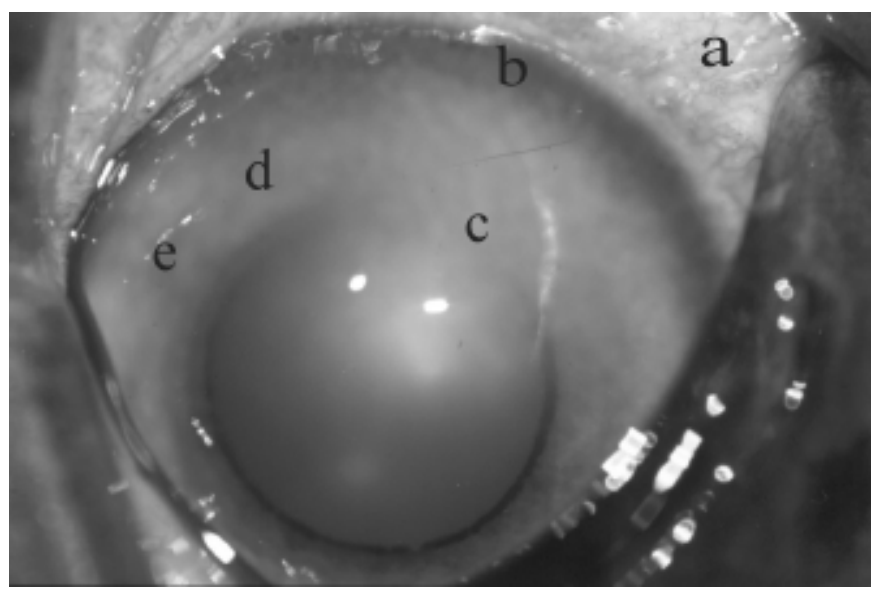

Figure 2: Eye of a dog. Note the episcleral congestion (a), ciliary flush (b), corneal edema (c), iris swelling (d), and rubeosis iridis (e).

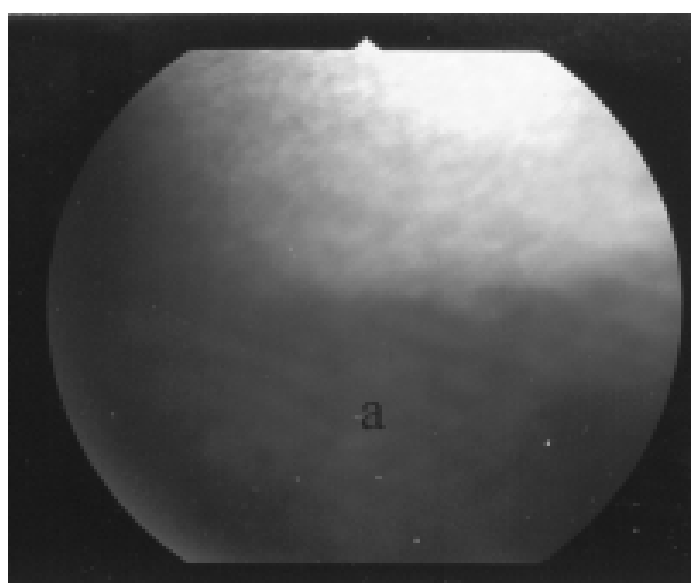

Figure 3: Diffuse preretinal hemorrhage (a) in a dog. 


\section{Serologic findings (IFAT and DBELIA)}

Dense fluorescent intracytoplasmic clusters of organisms (morulae) were seen in samples positive to IFAT (Fig. 4a). Fluorescence for $E$. canis antibodies was present in 34 samples, and the remaining 17 were negative (Fig. 4b).

In the IFAT test for Babesia sp, 24 out of the 51 examined were positive at a 1:80 dilution.

For the DBELIA test a positive reaction was confirmed by the appearance of a greyish color on the lower spot of the Immunocomb ${ }^{\circledast}$ test (BIOGAL). The color and intensity indicated the presence of anti-E. canis specific IgG antibodies. Absence of color at the lower spot on the comb indicated a negative reaction.

Forty four samples were DBELIA positive, showing variable intensity of reaction. The $1 \%$ difference between the DBELIA and IFAT tests using Fishers Exact Test was significant $(p<$ 0.05 ). The measured associated number of positive and negative animals by the Pearsons Correlation Test was 0.564 .
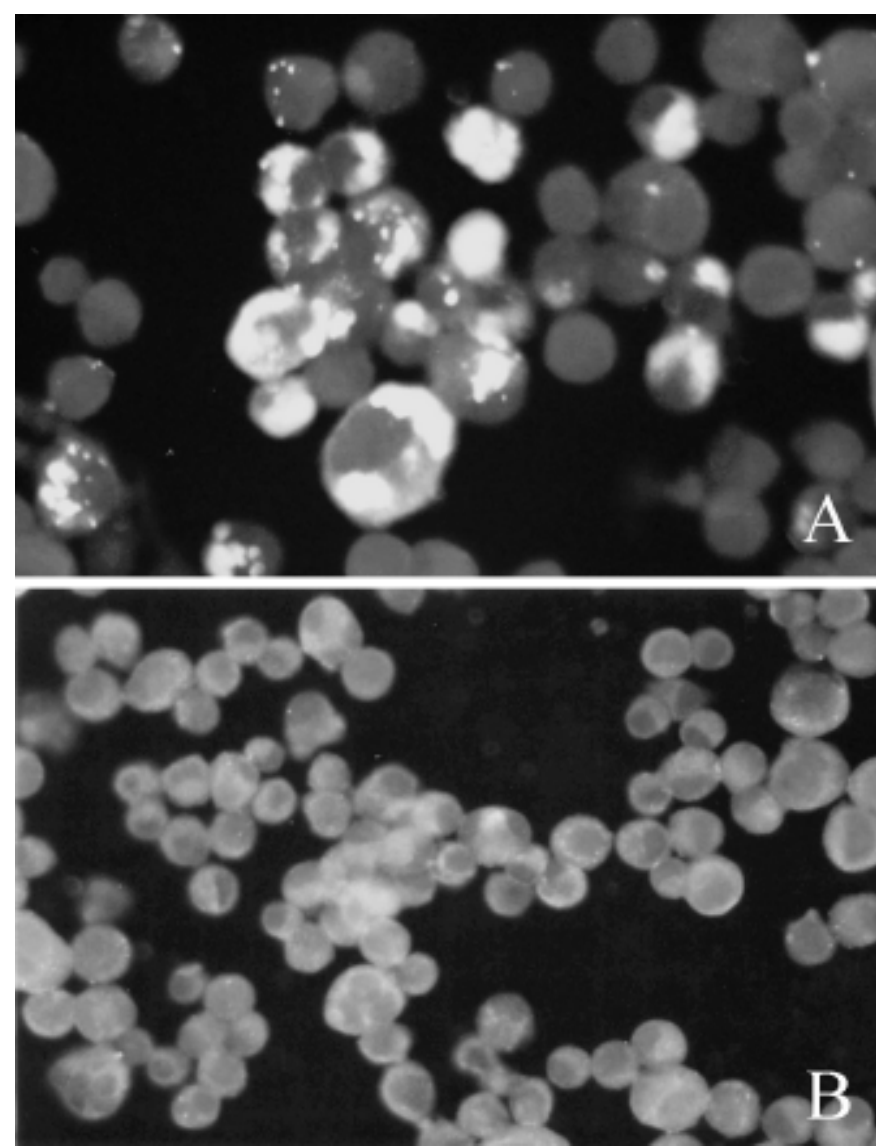

Figure 4a: Appearance of a positive reaction observed from an aqueous sample in the IFAT test for antibodies to Ehrlichia canis 100x.

Figure 4b: Appearance of a negative reaction observed in the IFAT test for antibodies to Ehrlichia canis 100x.

\section{Hematological tests}

The hematological findings for the dogs with positive serology by DBELIA revealed significant differences (Fig. 5) with a most samples showing a decreased red cell and a severe decrease in the platelet counts respectively.

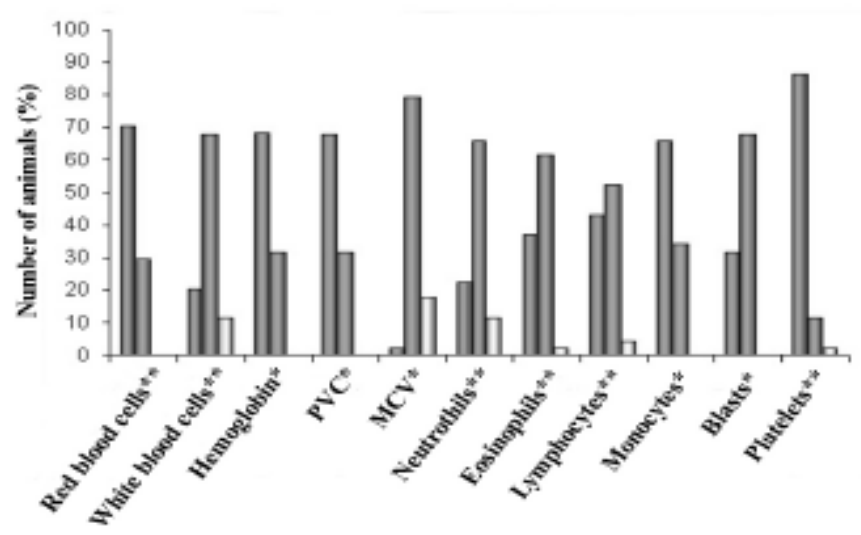

Figure 5: Hematological results for the DBELIA positive animals.

\section{Discussion}

In the IFAT testing, $66.67 \%$ of the animals were positive, but for the DBELIA tests, $86.27 \%$ were positive. The result of the measured associated number of positive and negative animals by Pearsons Correlation Test was 0.564 , differing from that which had been previously recorded in terms of test sensitivity. This advantage of DBELIA over IFAT testing has been previously reported by Cadman et al. (1994).

The serological titers obtained by DBELIA varied widely so that correlation between the titers and the ocular damage could not be established. It has been previously reported that humoral antibody does not necessarily influence the intensity of infection (Nyindo et al., 1980), and the results of this study suggest ehrlichiosis cellular damage does not always correlate to humoral immunity.

In the DBELIA positive dogs the most commonly identified hematological abnormalities were anemia in $70.5 \%$ of the animals and thrombocytopenia. The causes of anemia in dogs with ehrlichiosis are difficult to establish, as has been previously reported (Kuehn and Gaunt, 1985). However, two mechanisms are probably involved: the first is red cell mobilization through the monocytic/macrophage system and subsequent lysis of these cells due to complement action (hypersensitivity reaction type (I), and the second the suspension of medullary erythropoiesis (Castro, 1997).

In the DBELIA serologically positive dogs, $84.36 \%$ dogs exhibited thrombocytopenia, which is the most frequent significant event in all stages of ehrlichiosis. However thrombocytopenia as a non-pathognomonic sign of the disease (Harrus et al., 1997). Among the factors involved in the genesis of thrombocytopenia are bone marrow aplasia, suppression of erythrocyte, leukocyte and thrombocyte formation, as well as platelet depletion due to immunomediated mechanisms (Harrus et al., 1996).

Comparison of the ophthalmic and hematological findings in the dogs, which had positive serology for E. canis, suggests several conclusions. The hematological results did not always correspond with the level of ophthalmic involvement. Depression, decrease in food intake or even anorexia, and weight loss usually occurs in animals with ehrlichiosis (Hibler et al., 1986). Epistaxis was not seen in this survey. In some thrombocytopenic animals with severe uveitis, conjunctival and scleral hemorrhages were probably due to thrombocytopenia. 


\section{Conclusions}

This study demonstrates high correlation between the clinical uveitis and positive serology for E. canis. The DBELIA test was more sensitive for the diagnosis of ehrlichiosis than IFAT.

\section{Acknowledgements}

The authors acknowledge the Dr. Gener Tadeu Pereira for statistical analysis, Dr. Leonardo Pinto Brand?o for his technical support and Dr. Marlos Gonsalves and Aline Pontes Oriá for their help in the english version.

\section{References}

CADMAN, H.F.; KELLY, P.J.; MATTHEWMAN, L.A. et al. Comparison of the dot-blot enzyme linked immunoassay with immunofluorescence for detecting antibodies to Ehrlichia canis. Vet. Rec., v. 8, n. 135, p. 362, 1994.

CASTRO, M.B. Avaliação das alterações hematológicas, imunológicas e anatomopatológicas na infecção aguda experimental de cães por Ehrlichia canis (Donatien e Lestoquard, 1935) Moshkovski 1945. 1997. 69 f. Dissertação (Mestrado) — Faculdade de Ciências Agrárias e Veterinárias, Universidade Estadual Paulista, Jaboticabal. 1997.

CLERC, B.; LAFORGE, H. Ocular manifestations of systemic disease. In: ETTINGER, S.J.; FELDMAN, E.C. (Ed.). Textbook of Veterinary Internal Medicine. 3. ed. Philadelphia:W.B. Saunders, 1999. p. 524-532.

COLLINS, B.K.; MOORE, C.P. Disease and surgery of the canine anterior uvea. In: GELATT, K.N. (Ed.). Veterinary Ophthalmology3. ed., Lippincott Williams \& Wilkins: Philadelphia, 1999; p. 755- 796.

D‘ELL PORTO, A. Estudo da ocorrência de Babesia canis (Piana e Galli Valério, 1895) em cães de rua da cidade de São Paulo. Avaliação de métodos de diagnóstico e características do quadro hemático. 1986. 95 f. Tese (Doutorado) - Instituto de Ciências Biomédicas, Universidade de São Paulo, São Paulo, 1986.

EVERMANN, J.F. Laboratory diagnosis of viral and rickettsial infections. In: GREENE, C.E. (Ed.). Infectious diseases of the dog and cat. 2. ed., Philadelphia:W.B. Saunders, 1998, p. 1-6.

GLAZE, M.B.; GAUNT, S.D. Uveitis associated with Ehrlichia platys infection in a dog. J. Am. Vet. Med. Ass., v. 188, n. 9, p. 916-917, 1986.
HARRUS, S.; WANER, T.; WEISS, D.J. et al. Kinetics of serum antiplatelet antibodies in experimental acute canine ehrlichiosis. Vet. I $\mathrm{mm}$. Immunopathol., v. 5, p. 13-20, 1996.

HARRUS, S.; BARK, H.; WANER, T. Canine monocytic ehrlichiosis: an update. Comp. Cont. Educ. for Vet., v. 5, n. 1, p. 9-16, 1997.

HIBLER, S.C.; HOSKINS, J.D.; GREENE, C.E. et al. Rickettsial infections in dogs Part II. ehrlichiosis and infectious cyclic thrombocytopenia. Comp. Cont. Educ. for Vet., v. 8, n. 2, p. 106-113, 1986.

KUEHN, N.F.; GAUNT, S.D. Clinical and hematologic findings in canine ehrlichiosis. J. Am. Vet. Med. Ass., v. 186, n. 15, p. 355-358, 1985.

MARTIN, C.L. Ocular Manifestations of systemic disease. In: GELATT, K.N. (Ed.). Veterinary Ophthalmology 3. ed., Philadelphia: Lippincott Williams \& Wilkins, 1999. p. 1401-1447.

NEER, T. M. Canine monocytic and granulocytic ehrlichiosis. In: GREENE, C.E. (Ed.). Infectious diseases of the dog and cat. 2. ed., Philadelphia:W.B. Saunders, 1998. p. 139-147.

NYINDO, M.; HUXSOLL, D.L.; RISTIC, M. etal. Cell-mediated and humoral immune response of German shepherd dogs and beagles to experimental infection with Ehrlichia canis. Am. J. Vet. Res., v. 41, n. 2, p. 250-254, 1980.

RISTIC, M.; HUXSOLL, E.L.; WEISIGER, R.M.; et al. Sorological diagnosis of tropical canine pancytopenia by indirect immunofluorescence. Infec. Imm., v. 6, n. 3, p. 226-236, 1972.

STILES, J. Canine rickettsial infections. Vet. Clin. North. Am. Small. Anim. Prac., v. 30, n. 5, p. 1135-1149, 2000.

TROY, G.C.; FORRESTER, S.D. Canine ehrlichiosis. In: GREENE, C.E. (Ed.). Infectious diseases of the dog and cat. 1. ed., Philadelphia:W.B. Saunders, 1990, p. 48-59. 